\title{
Şizofreni Hastalarının Sosyal Yaşamları ve Sosyal Hizmet İliş̧kisi: Kütahya İli Örneği
}

\author{
Figen VURAL*, Muhammet Ali KÖROĞLU**
}

ÖZ

Şizofreni hastalığı, ağır psikiyatrik hastalıklardan biridir. Bu hastalık, bireyi fiziksel olarak etkilediği gibi psikososyal açıdan da etkilemektedir. Bu çalışma; şizofreni tanısıyla tedavi gören bireylerin hastalık ile baş etme stratejilerini, aileleri ve çevreleriyle olan ilişkilerini, aldıkları kurumsal sosyal destek çerçevesinde değerlendirmeyi amaçlayan, Sosyal Hizmet bilim dalı perspektifinden gerçekleştirilmiş nitel bir araştırmadır. Çalışmaya katılmayı kabul eden şizofreni tanısı almış, Kütahya İlinde yaşayan ve Kütahya S.B.Ü. Evliya Çelebi Eğitim ve Araştırma Hastanesi'nden hizmet alan kişi sayısı 9'dur. Bu 9 katılımcının 3'ü kadın, 6'sı erkektir. Çalışma ile birlikte; hastanın psiko-sosyo-ekonomik destek varlığının hastalığın sağaltımına etkisi açıklanmış ve çalışma sonucunda da bu durumun, hastaların tedaviye uyum sağlamalarını kolaylaştırdığı belirlenmiştir. Bunun yanında, hastaların farkındalığının sağlandığı görülmüştür. Hastanın tedaviye uyumunu artırmak için kullandığı ilaçlar hakkında eğitim verilmesi ve sosyal çevrelerinin sürece dahil edilmesi verilebilecek önerilerdendir. Bireylerin sosyal yaşamda daha fazla yer almaları sağlanarak; tedaviye uyumlarının artacağı, günlük yaşamın gereklerini yerine getirebilecek durumda olmalarına katkı sağlayacağı düşünülmektedir.

Anahtar Kelimeler: Şizofreni, Sosyal Hizmet, Sosyal Destek, Sosyal Yaşam

JEL Sinıflandırması: I10, I12, I19

\section{Social Life and Social Work Relationship of Schizophrenic Patients: Kütahya Sample}

\begin{abstract}
This study is a qualitative research conducted from the perspective of Social Work, which aims to evaluate the strategies of coping with the disease, their relationships with families and the environment, of individuals treated with the diagnosis of schizophrenia, within the framework of the institutional social support they receive. He was diagnosed with schizophrenia who accepted to participate in the study, living in Kütahya Province and Kütahya S.B.Ü. Evliya Çelebi Training and Research Hospital. The number of people receiving service is 9. With the study, the effect of the presence of the patient's psycho-socio-economic support on the treatment of the disease was explained, and as a result of the study, it was determined that this situation facilitates the patients' compliance with the treatment. It is thought that their compliance to treatment will increase and they will contribute to being in a condition to fulfill the requirements of daily life.
\end{abstract}

Keywords: Schizophrenia, Social Work, Social Support, Social Life

JEL Classification: I10, I12, I19

Geliş Tarihi / Received: 05.06.2020 Kabul Tarihi / Accepted: 16.06.2020

\footnotetext{
* Sosyal Hizmet Uzmanı, Uşak Üniversitesi, Lisansüstü Eğitim Enstitüsü, Sosyal Hizmet Anabilim Dalı, figen.vr193@gmail.com, ORCID: 0000-0002-4076-0114

** Dr. Öğr. Üyesi, Uşak Üniversitesi, İİBF, Sosyal Hizmetler Bölümü, muhammet.koroglu@usak.edu.tr, ORCID: 0000-0001-8593-6139
} 


\section{GİRİş}

Şizofreni; kronik olarak seyreden bir hastalıktır. Genetik faktörlü olabileceği gibi stres faktörü, olumsuz çevre etmenleri, olumsuz sosyal koşullar da hastalığa sebep olmaktadır. Uzun süreli tedavi gerektiren bu hastalık; hastanın sosyal yaşamını, ilişkilerini, tutum ve davranışlarını olumsuz yönde etkilemektedir. Hastalıkla birlikte bireyde; aşırı uyku hali, agresiflik, tutarsız duygu ve davranış, gerçekle hayali karıştırma gibi belirtiler görülmektedir. Bunun yanında hastada; kilo kaybı veya kilo artımı, kendi kendine konuşmalar, dikkat dağınıklığı, fikir uçuşmaları, anlamsız cümle kurma ve anlamsız konuşmalar görülmektedir.

Şizofreni; bireyde normal olmayan davranış ve tutumların görüldüğü, her bireyde farklı belirtilerinin ortaya çıktığı, çok yönlü bir hastalık olarak bilinmektedir. Bir başka tanıma göre şizofreni; genç yaşta başlayan, bireyin gerçeklerden uzaklaşmasına, içe kapanmasına neden olan; duygulanımda, düşünce içeriğinde daralma, azalma görülen bir psikozdur. Hastalığın oluşmasında çevresel etmenler, biyolojik etmenler gibi çok çeşitli faktörler bulunur. (Aktürk Demir, 2011, s.228).

Şizofreni ile birlikte hastanın yaşamında da çeşitli değiş̧iklikler olmaktadır. Hasta, tedavisi gereği uzun ve yoğun bir şekilde ilaç kullanımına maruz kalmaktadır. Bu ilaç kullanımı; hastanın sosyal yaşamını da olumsuz etkilemekle beraber, hastanın tedaviye uyumsuzluğunu da birlikte getirmektedir. Şizofreni hastalarında ilaç kullanımı ile birlikte; hareketlerde yavaşlama, aşırı uyku hali, çabuk yorulma gibi belirtiler görülmektedir. Tedaviye uyumsuz olan ve direnç gösteren hastalarda, ilaç tedavisine ek olarak psikoterapiler ve elektrokonvülsif tedavi (EKT) kullanılabilir. EKT; kafaya elektrik verilerek hastaya nöbet geçirtip, beyne reset atılmasıdır (Erbaş, 2018).

Şizofreni tanısı alan birey için sosyal destek örüntüleri önemlidir. Sosyal ağı kuvvetli olan birey; ilaç tedavisine uyumla birlikte, hastalığın getirdiği olumsuzluklarla baş edebilmeyi sağlamakta ve rutin hayatın gereklerine uygun davranabilmektedir. Sosyal hizmet müdahale planı geliştirirken; birey ve bireyin sosyal ağlarını da dikkate alarak, hastanın hastaneye yatış oranının azalmasını, hastalığın dengeli seyretmesinin sağlanmasını, hastanın kendi kendine yetebilirlik durumunun artırılmasını sağlar.

Hastalığa sahip birey; hastalığın beraberinde getirdiği olumsuz durumları yaşamak zorunda kalırken, hastanın yaşadığı bu olumsuzluklardan hastanın sosyal çevresi ve ailesi de etkilenmektedir. Şizofreni hastalarının en büyük destekçileri ailesi olmaktadır. Birey hastalığın belirtileri ile baş etmeye çalışırken, ailesi de kendi rol ve sorumluluklarına eklenen yeni görevleri anlamaya ve hasta olan bireye yardımcı olmaya çalışmaktadır. Böylece sosyal desteğin önemi anlaşılmaktadır. Çevresi içinde birey yaklaşımından hareketle; ağır psikiyatrik rahatsızlıklardan olan şizofreni hastalığının tedavisinde, sosyal boyut anlam kazanmaktadır. Bu boyutta hasta olan bireye ve ailesine destek sağlayan mesleklerden biri de sosyal hizmettir. Sosyal hizmet birey ve ailesi ile çalışırken, onların güçlü yanlarına vurgu yaparak; hasta ve ailesinin hastalık ile baş etme mekanizmalarını geliştirmek, ayrımcılığa maruz kalmadan toplum içerisinde bütünleşmelerini sağlamak adına hasta ve ailesine yardımcı olmak amacındadır.

\subsection{Psiko-sosyal Bir Hastalık Olan Şizofreni}

Şizofreni; erken yaşlarda başlayan, bireylerin kişilerarası ilişkilerinden ve gerçek yaşamdan koparak, kendilerine has bir içe kapanma durumlarının olduğu, duygu düşünce ve davranışlarda önemli bozuklukların görüldüğü bir psikozdur. En bariz özelliği, gerçeği değerlendirme yetisinin bozulmasıdır. Bununla beraber algılamada, düşünce içeriğinde, hareketlerde bozulmalar görülür. Hastalığın oluşmasında tek bir etken belirleyici değildir. Ancak genetik, çevresel ve stres faktörlerinin etkili olduğu ifade edilmektedir. Hastalığın tedavisinde öncelikli tedavi, ilaç tedavisidir. Ancak ilaç tedavisinin yanında, özellikle ilaç tedavisine cevap 
vermeyen hastalarda, EKT (elektrokonvülsif tedavi) de tercih edilir. Ayrıca vakalarda psikoterapiden de yararlanılmaktadır (Aktürk Demir, 2011). Başka bir tanıma göre ise şizofreni; alevlenme ve yatışma dönemleri ile birlikte seyreden kronik bir psikiyatrik rahatsızlıktır. Alevlenme ve yatışma dönemlerinde farklı belirtiler bulunmaktadır. Hastalı̆̆ın alevlenme döneminde, özellikle düşünce ve algılama bozuklukları görülmektedir. Örneğin; birey takip edildiği düşüncesinde olabilmekte ve ortada ses, görüntü olmamasına rağmen bunları varmış gibi algılayabilmektedir. Bu hezeyanı, halüsinasyonu yaşayan kişi çevresine karşı olumsuz tutumlar da sergilemektedir (Yakınc1, 2015).

Şizofrenide en yaygın görülen türler; katatonik ve paranoid şizofrenidir. Paranoid şizofrenide; sanrılı düşünceler hastanın davranışlarında oldukça etkilidir. Birey, her şeye şüpheci yaklaşmaktadır. Katatonik şizofreni de ise; hastalar çok aktiftirler, saldırgan tarzda davranış gösterirler ya da çok hareketsizdirler (Cüceloğlu, 2011). Katatonik şizofrenide hastalar saatlerce sabit kalabilirler, bu hareketsizlikleri yaşamları için tehlike arz edebilecek derecede olabilmektedir. Paranoid şizofreni de ise; hastalar şüphecilik ile baş etmek zorunda kalırlar. Zehirleneceklerini düşünebilmektedirler, takip edilme duygusu peşlerini bırakmayabilir. Her iki tip şizofrenide de sosyal yaşam olumsuz etkilenmektedir ve aile bağları sarsılabilmektedir.

Ruh sağlı̆̆1 bozulan bireylerde; tutarsızlık, aşırılık, yetersizlik, çöküntü, ilgisizlik, gerçeklik algısında bozulma özellikleri görülür. Ruh sağlığının bozulmasında demografik, çevresel, psikolojik etkenler belirleyici olabilmektedir (Hökelekli, 2009). Şizofreni hastalarının hastalıkları ile ilgili yaşadıkları bu sorunlar; bireylerin toplumsal yaşam içerisinde, günlük yaşamın gereklerini yerine getirmekte dahi zorlanmalar yaşamalarına neden olmaktadır. Örneğin; bir konuşmayı dinlerken veya dikkat gerektirecek bir iş yaparken odaklanma sorunu yaşayabilmektedirler. Konuşma esnasında, düşünce akışında düzensizlikler olabilmektedir ve konudan konuya kolayca atlayabilmektedirler.

Şizofreni hastalı̆̆ başlamadan, hastalığın öncesinde uyarıcı belirtilerin olduğu bir süreç bulunmaktadır. Bu uyarılar; gerginlik hali, sinirlilik, uyku düzeninde bozulma, depresif duygu durumu olabilmektedir. Uyarılar dikkate alınıp, erken sağaltım olursa hastalar hızlı bir iyileşme süreci gösterebilmektedir (Deveci, Esen Danacı, 2006). Hastalık belirtileri yoğunlaşmadan önce bir takım uyarıcı belirtilerin bulunması ve bu belirtilerin bireyin çevresindekiler tarafindan fark edilmesi, hastanın hastalık dönemini şiddetli bir şekilde geçirmemesini sağlayabilmektedir. Böylece hastaya erken müdahale edildiğinde, hastada sağaltım olmaktadır.

\section{2. Şizofreni ve Sosyal Yaşam}

Şizofreni tanısı bulunan bireylerin yaşamı değişir. Sosyal olarak içe çekilme, iletişim kurmada sorunlar yaşama, duygusal tepki verebilmede zayıflık gibi durumlar yaşanır. Şizofreni hastaları; çevreden uzaklaşıp içine kapandıkça iletişimden de yoksun kalırlar ve iletişim yoksunluğunu, sanrılardan gelen görüntü ve sesler ile iletişime geçerek gidermeye çalışırlar (Köknel, 2013). İletişime kapalı bir bireyin mutsuzlaşması, özgüven kaybı yaşaması, kendini ifade etmede zorlanması siklıkla görülen bir durumdur.

$\mathrm{Bu}$ durumdaki hasta; sağlıkla ilgili önerileri kabul edip ilaçlarını kullanmaya düzenli olarak devam ettiğinde, tedaviye uyum sağlamış olur (Demirkol, Tamam, 2016). Hasta tedaviye uyumsuzluk gösterdiğinde ise; hastaneye yatış oranı ile birlikte aile ilişkileri ve sosyal çevresi ile yaşadığı sorunlar da artmaktadır. Bunun aksine, toplum tarafından kabul edilebilir davranışları azalmaktadır. Şizofreni düzenli ilaç kullanımı gereken bir hastalıktır fakat hastaların çoğu hastalığını kabul etmeyerek ilaç kullanmaları gerektiğini inkâr ederler. Bu durum, ilaç uyumsuzluğunu beraberinde getirir. Bu nedenle hastaların, ilaç kullanımını doktor kontrolü olmadan bırakabildikleri görülür. Bunun sonucunda, şizofren hastalığının belirtileri artmakta ve hastaların yaşam kalitesi düşmektedir. 
Şizofreni hastalarının yaşam kalitesini ve sosyal yaşamını etkileyen diğer faktörlerden biri de bağımlılıktır. Şizofreni hastalarında sigara kullanım oranı yüksek olduğundan; hastanın yaşam kalitesi, hastalığın gidişatı olumsuz olarak etkilenmektedir. Hastaların hastaneye yatışı artmaktadır (Karşıdağ, Alpay, Kocabıyık, 2005). Sigara içen şizofreni hastaları; normal nüfusa göre daha çok sigara içtiklerinden, nikotin bağımlılı̆̆ 1 daha fazla olmaktadır. Böylece daha çok tıbbî hastalık tanısı almakta ve sigarayı bırakma eylemleri daha az olmaktadır. Bu durum aynı zamanda hastaların ilaç tedavilerini de olumsuz etkilemektedir (Dilbaz, Enes Darçın, 2011).

Yaşam kalitesini ve tedaviyi olumlu yönde etkileyen en önemli unsur, ailedir. Şizofren hastalar için bakım verenler genelde aile üyeleri olmaktadır. Aile üyeleri hastada olan değişimleri fark ederler. Hastanın anlamsız bakışları, olumsuz tavırları, korku, uyuyamama gibi davranışlarını gözlemlerler (Bademli, Çetinkaya Duman, 2013). Böylece hastalığın farkına erken vararak, hastanın tedavisini bir an önce düzenlenmesine yardımcı olurlar. Nitekim şizofreni hastasındaki duygu, düşünce ve davranışlardaki bozulma; hasta kadar hastanın ailesini de etkilemektedir. Toplumun şizofreni hastalarına olumsuz bakışı, ailenin yükünü artırmaktadır. Bu nedenle aileleri de hastanın sağaltımına katabilecek psiko-sosyal uygulamalar artırılıp, yaygınlaştırılmalıdır (Gülseren, 2002). Bu anlamda, sosyal hizmetin şizofreni hastalarında sağaltım rolündeki etkisi önem arz etmektedir.

\section{3. Şizofreni ve Sosyal Hizmet}

İnsan doğası gereği biyo-psiko-sosyal bir varlık olarak çok boyutlu değerlendirilmelidir. $\mathrm{Bu}$ yüzden de disiplinler arası bir çalışma gereklidir. Sosyal hizmet insan davranışını ve onun etkileşim içine girdiği sosyal çevreyi değerlendirmek ve uygulama geliştirebilmek için bu disiplinlerden yararlanır (Danış, 2007). Sosyal hizmet; çevresi içinde bireyi ele alırken, bireyin ailesini ve sosyal çevresini de müdahale planına dâhil eder. Çünkü bireyin yaşadığı sorunların çözümünde, bireyin ailesi ve çevresi önemlidir (Özbesler, 2011).

Sosyal hizmet; bireylerin iyilik hallerini artırmaya çalışan, bireyi çevresi içinde değerlendirmeyi hedefleyen bir meslektir ve bilim disiplinidir. Tıbbî alanda da çalışma sahası bulan Sosyal Hizmet, disiplinler arası bir çalışma yürütür. Hastanın sosyal çevresi, aile içi ilişkileri bireyin hastalığını etkilediğinden; hastanın sosyal çevresindeki faktörlerin hastalık üzerindeki etkileri değerlendirilir. Böylece hastanın baş etme becerileri artarken, iletişim becerileri de gelişir (Hasgül, 2016).

Tıbbî sosyal hizmetin alt dallarından birisi olan Psikiyatrik Sosyal Hizmet; ruh sağlı̆g 1 konusunda problemleri olan kişilere hizmet verir. Bu anlamda ruh sağlığı ile ilgili sorunlar yaşayan müracaatçılarla çalışan sosyal hizmet uzmanlarının; müracaatçıların ihtiyacı ile kaynağı birleştirmek, toplumsal sistemlerle olan ilişkilerini düzenlemek gibi rolleri vardır (Bulut, 2001, 130-134, Akt: Iş1khan, 2006, 45).

Tüm dünyadaki sosyal, ekonomik, teknolojik değişiklikler, tıptaki gelişmeler hastaya bakış açısında yeni yaklaşımlar getirmiştir. Psikiyatrik hasta sayılarının toplumda giderek görünürlügünün artması, aile yapısındaki değişimler gibi nedenlerle de tıbbî sosyal hizmetin önemi artmıştır. Şizofreni hastalarının yaşadıkları ayrımcılık, aile desteğinin yetersiz kalması veya şizofreni hastalarında aile desteğinin kaybedilmesi gibi sorunlar; bu alanda hizmet veren meslek elemanlarının, hastaların, ailelerinin ve toplumun bilinçlendirilmesi açısından önem arz etmektedir. 


\section{YÖNTEM}

Araştırma, nitel araştırma yöntemi kullanılarak yapılmıştır. Verilerin toplanabilmesi amacı ile yarı yapılandırılmış görüşme formu ve katılımlı gözlem tekniklerinden yararlanılmıştır. Araştırma verilerine daha kolay ulaşılabilir olması nedeniyle araştırma; Kütahya S.B.Ü. Evliya Çelebi Eğitim ve Araştırma Hastanesi’nde yapılmıştır. Araştırma Kütahya İlinde yaşayan ve araştırmanın yapıldığı hastaneden hizmet alan şizofreni hastaları ile yapılmıştır. Bu çerçevede 27.01.2020-27.03.2020 tarihleri arasında 9 katılımcıya (3 kadın, 6 erkek) gönüllülük esası kullanılarak ulaşılmıştır.

Araştırmaya başlamadan önce Uşak Üniversitesi Bilimsel Araştırmalar Etik Kurulu'ndan ve araştırmanın yapıldığı Kütahya S.B.Ü. Evliya Çelebi Eğitim ve Araştırma Hastanesi’nden yazılı izin alınmıştır. Sosyo-demografik formda; yapılan çalışmaya ilişkin bilginin yanında, 7'si demografik bilgileri içerecek şekilde ve sonuncusu hastaların son sözü olarak eklenilmek istenen bilgiyi içerecek şekilde olmak üzere 26 soru sorulmuştur. Şizofreni hastalarının hastalıkla birlikte yaşadıkları sorunları daha iyi ifade edebilmeleri için hastalara açık uçlu sorular sorulmuştur. Katılımcılar tarafından verilen cevaplar, araştırmacı tarafindan not tutmak suretiyle kaydedilmiş ve yine araştırmacı tarafından yorumlanmıştır.

\section{BULGULAR}

Katılımcıları sosyo-demografik özellikleri açısından değerlendirdiğimizde; katılımcıların 3'ü kadın, 6'sı erkek şizofreni hastasıdır. Katılımcıların yaş ortalaması 41,4'tür. Kadınların yaş ortalaması 33, 6 iken, erkeklerin yaş ortalaması 45, 3’tür. Sonuca göre katılımcı kadınların yaş ortalaması, katılımcı erkeklere göre daha düşük bulunmuştur. Katılımcıların 4'ü ilde, 2'si ilçede, 2'si köyde yaşamaktadır. Diğer 1 katılımcı ise kasabada yaşamaktadır. İlde yaşayan 4 kişinin 3'ü erkektir, 1'i kadındır. İlçede yaşayan 2 kişinin 2'si de yatılı bakım merkezinde kalmaktadır. Bu 2 kişinin 1'i erkek, 1'i kadındır. Köyde yaşayanların her ikisi de erkektir. Araştırmaya katılan kişilerin çoğunun il merkezinde yaşıyor oluşu, kendilerine sağlanan haklardan yararlanma ihtimallerinin diğer katılımcılara göre daha yüksek olduğunu göstermektedir. Araştırmaya katılan kişilerin 4'ü lise mezunudur. Diğer 3 kişi ise ilkokul, ortaokul, lisans ve yüksekokul mezunudur. Diğer 1 kişi ise okuryazar değildir. Lise mezunu 4 kişinin 3'ü erkek, 1'i kadındır. Okuryazar olmayan ve lisans mezunu (sosyolog) olan kişiler de kadındır. İlkokul, ortaokul ve yüksekokul mezunu (elektrik teknikeri) kişiler erkektir. Bu durum; her türlü eğitim düzeyine sahip bireyin, şizofreni hastalığına yakalanma riskinin olduğunu göstermektedir.

Katılımcıları medeni durum açısından değerlendirdiğimizde; 3'ü evli, 3'ü bekârdır ve 2'si eşinden boşanmıştır. Diğer katılımıının ise eşi vefat etmiştir. Evli olan 3 kişinin 3 'üde erkektir. Bu kişilerin 2'si ilde, 1'i köyde yaşamaktadır. Bekâr olan 3 kişinin 2'si erkek, 1'i kadındır. Bu kişilerden 2'si ilde, 1'i ilçede yaşamaktadır. Boşanmış olan kişilerin 1'i kadın, ilçede ve 1'i erkek köyde yaşamaktadır. Eşi vefat eden kişi kadındır ve kasabada yaşamaktadır. Elde edilen veriler, şizofreni tanısı almış kişilerden cinsiyeti erkek olanların evliliğe daha yatkın olduğunun göstergesi sayılabilir. Bekâr ve boşanmış kişilerin katılımcıların yarıdan fazlasını oluşturuyor oluşu, hastalığa sahip bireylerin hastalığından kaynaklı olarak evlenemediklerinin veya evlenip boşandıklarının göstergesi olabilmektedir. Evli bireylerin aile desteğinin bulunduğu anlaşılmaktadır. Katılımcıların 3'ü emeklidir. 1'i çiftçi olarak kendi işini yapmaktadır. Diğer 5 katılımcı ise çalışmamaktadır. Emeklilerin tümü erkektir ve ilde yaşamaktadır; 2'si evli, 1'i bekârdır. Kendi işini yapan 1 kişi erkektir, evlidir ve köyde yaşamaktadır. Çalışmayan 5 kişinin 4'ü kadın, 1'i erkektir. Çalışmayan 5 kişinin 2'si yatılı bakım merkezinde kalmaktadır, bunlardan 1'erkek diğeri kadındır, 1'i boşanmıştır, diğeri bekârdır ve 2'si de ilçede yaşamaktadır. Çalışmayan kişilerden erkek olan köyde yaşamaktadır, ilkokul mezunudur ve eşinden boşanmıştır. Diğer çalışmayan 2 kadından 1'i bekârdır, lisans mezunudur ve ilde 
yaşamaktadır; diğeri ise kasabada yaşamaktadır, okuryazar değildir ve eşi vefat etmiştir. Veriler incelendiğinde, lisans mezunu sosyolog olan kişinin hastalığından dolayı işini yapamadığı düşünülmektedir. Bu açıdan hastalığın sadece bireyi değil, aynı zamanda bireyin sosyoekonomik yaşamını da olumsuz etkilediği görülmektedir.

Araştırmaya katılanlardan $500 \mathrm{TL}$ ve altı aylık gelire sahip olan kişi sayısı 4'tür. Bu 4 kişinin 2'si kadın, 2'si erkektir. 1 kadın ve 1 erkek yatılı bakım merkezinde kalmaktadır. Bu katılımcılardan geriye kalan 2 kişi de çalışmamaktadır. Aylık geliri 1000 TL olan 1 kişi; çiftçilikle uğraşan, evli, ortaokul mezunu, köyde yaşayan, erkektir. Aylık geliri 2350 lira olan 1 kişi; kasabada yaşayan, eşi vefat etmiş, okuryazar olmayan, kadındır. Aylık geliri 3000 TL olan 1 kişi; ilde yaşayan, lise mezunu, evli, emekli, erkektir. Aylık geliri 4700 TL olan 1 kişi; ilde yaşayan, yüksekokul mezunu, bekâr, emekli, erkektir. Aylık geliri 6100 TL olan 1 kişi; ilde yaşayan, lise mezunu, evli, emekli, erkektir. 2020 yılı net asgari ücret 2.324, 74 TL olduğu baz alındığında araştırmaya katılan 9 kişinin 5 'i asgari ücretin altında bir aylık gelire sahiptir. Katılımcılardan 2'si askeriyeden emekli olup 6100 TL ve 4700 TL geliri sahiptir. Şizofreni hastalığı bulunan kişilerin aylık gelirlerinin düşük oluşu ekonomik açıdan desteğe ihtiyacı olduklarının bir göstergesi sayılabilmektedir.

9 şizofreni hastasının 3'ü herhangi bir sosyo-ekonomik yardım almazken; diğer 6's1 bakım maaşı, bakım merkezinde kalmak, TCDD'den yararlanmak, ücretsiz otobüs kartı, indirimli su, malulen emeklilik, muhtardan yardım alarak sosyoekonomik destek sağlamaktadırlar. Herhangi bir sosyo-ekonomik yardım almayan 2 kişinin aylık düzenli bir geliri bulunurken, diğer 1 kişinin herhangi bir geliri yoktur. Bu kişilerin 2'si kadın, 1'erkektir. Herhangi bir sosyo-ekonomik yardım alan kişilerden çoğu, birçok yardımı aynı anda almaktadır. Bakım maaşı alan ve malulen emeklilikten faydalanan 2'şer kişidir. Ücretsiz otobüs kartı kullanan 2 kişidir. Bu kişiler il merkezinde yaşamaktadırlar ve bu kişilerin toplumsal katılımda bulunmaları, sosyal çevresi ile ilişki içerisinde olmaları için ücretsiz otobüs kartı uygulaması bireyler için önemli bir faydadır. Şizofren hastalarının bakım maaşı ve malulen emeklilik haklarından faydalanıyor oluşu, hastalıklarından kaynaklı olarak bakıma muhtaç konumda olduklarının ve işlerini yapamayacak durumda kalıp emekli olduklarının göstergesi olabilmektedir. Buradan anlaşılacağı üzere hastalığın yıpratıcı ve yıkıcı etkisinin bireyler üzerindeki olumsuz yanı büyüktür.

Herhangi bir sosyal ekonomik yardım almayan 3 kişinin hastalıkları ile başa çıkma yöntemleri sorulduğunda hastalar; alışveriş yapmak, kitap okumak, spor yapmak, meşguliyet bulmak, televizyon izlemek, internette takılmak, uyumak yanıtlarını vermiştir. Herhangi bir sosyal ekonomik yardım alan 6 kişi hastalıkları ile başa çıkma yöntemlerine; Toplum Ruh Sağlığı Merkezi (TRSM) etkinliklerine katılmak, ilaç kullanmak, yalnızlık, kendisi ile sohbet etmek, susup kabullenmek, kendini tutmak, spor yapmak, aktivitelere katılmak cevaplarını vermiştir. Herhangi bir sosyal ekonomik yardım almayan 3 kişi ve alan 6 kişinin tamamının birlikte yaşadığ 1 bir aile üyesi vardır. Herhangi bir sosyal ekonomik yardım almayan 3 kişinin 2 'sinin vasisi bulunmaktayken, 1'nin vasisi yoktur. Herhangi bir sosyal ekonomik yardım alan 6 kişinin 3'ünün vasisi varken, 2'sinin vasisi yoktur ve 1 kişinin vasiliği önceden varken sonradan kaldırılmıştır. Herhangi bir sosyal ekonomik yardım almayan 3 kişinin 2 'sinin engelli sağlık kurulu raporu varken, 1'inin yoktur. Yardım alan diğer 6 kişinin 5'inin engelli raporu varken, 1'i engelli sağlık kurulu raporu almayı düşünmektedir.

Katılımcıların hastalığına neden olarak gördüğü önemli etkenler; bir yakınının vefatı, yalnızlık, ailevi sorunlar, askeri baskı, mesleğinden dolayı vurulma ve ölüm korkusudur. Bu nedenlerin, travmaya sebep olarak hastalığa yol açtığı görülmektedir. Aile kurumu ve iş hayatı çerçevesinde ortaya çıkan bir sorunun bireysel travmaya neden olduğu KATILIMCI 1'de de görülmektedir. KATILIMCI 1 "Hastalı̆̆ım mesleğimden dolayı 2006'da ölüm ve vurulma korkusu ile başladı. Şemdinli'de yanımda arkadaşım şehit oldu. Ondan sonra sorgulamaya 
başladım her şeyi. Evliydim, 23 yaşıında evlendim. 2 çocuğum vardı onlar o zaman Sivas'taydl. Şimdi çocuklarım işsiz, onlara kafayı takıyorum. Babam öldüğ̈̈nde de rahatsızlandım, onu çok seviyordum hala da kabullenemiyorum, üzülüyorum. $4 \mathrm{kez}$ psikiyatride yattım. Şizofren tanısı koydular. Psikiyatriye gitmeden önce hocaya götürdüler. Hoca, oğlun cinleri rahatsiz etmiş dedi ve bana muska yazdı ama kaybettim. ”SSeklinde yanıt vermiştir.

Katılımcı olan hastanın soruya ilişkin cevabı, hastalığının başlama sebebinin mesleğinden dolayı vurulma ve ölüm korkusu olduğudur. Bu korkusu hala devam etmektedir. Hatta hastanın bu korkusu sosyal yaşamını etkilemektedir. Nitekim sevdiği bir yakınını kaybetmekte, hastaların hastalıklarının seyrini olumsuz yönde değiştirebilmektedir. Katılımcı 1'de de olduğu gibi hastaların rahatsızlıkları başladığında çözüm ve çare arayışı olarak tıp bilimine değil, dini yönden kendisine yardımcı olabilecekleri kişilere başvurmaları dikkat çekicidir. Bu durum hastalığın tedavisiz geçen süresini artırmaktadır. Bu da hastayı işlevsiz hale getirmekte, hastanın yetilerini kullanamayacak duruma sokmaktadır. Dolayısıyla sadece hasta birey değil, çevresi de bu durumdan olumsuz etkilenmektedir. En sonunda da bir hastaneye gitmek zorunda kalınıp, tedaviye başlandığ görülmektedir. Buna ek olarak, sosyal desteğin önemi de bu katılımcının verdiği cevapla yeniden ortaya konulmuştur.

Bir diğer katılımcı ise hastalığının sebebini bir yakınını kaybetme sonucuna bağlamıştır. KATILIMCI 2 “1996-1997'de yüksekokula turizm otelcilik bölümüne gidiyordum, orda başladt. 23 yaşımdaydım. Askerliğimi hasta hasta yaptım 2000'de. Gerçekle hayali karıştırdım, hayata adapte olmakta güçlük çekiyordum. Aslen Afyonluyum. Annemin kanserden öleceğini doktordan duyduğumda duygularım patladl. O siralarda annem öldü, belki o yüzden olmuştur. İlk düşünce geçtikten sonra başka bir düşünce geliyor, ben o zaman ilk düşüncenin hayal olduğunu anllyorum. Manisa'da bir kez yattım. Düsüncelerimden kaynakll korkularım var benim. Afyon'dan köyümden kaçıp Akşehir'e kadar yürüyerek geldim. Beni öldürecekler diye kaçtım ama öyle bir şey yokmuş." Şeklinde kendini ifade etmiştir.

Katılımcı hastalığının başlangıcını bilememekle birlikte, hastalığın asıl sebebini annesini kaybetmesine bağlamaktadır. Şizofreni hastalığının tanımına uygun bir şekilde belirtiler yaşayan hastada; paranoyak düşünceler, gerçekle hayali ayırt edememe durumu, düşünce dağınıklığı, fikir uçuşması görülmektedir. Bir yakınının vefatı, bu vakada da travmaya neden olmuştur.

Diğer bir katılımcı sorunun cevabı olarak yalnız kalmasını ve hamilelik sürecinin hastalığının başlangıcına olumsuz etki ettiğini belirtmiştir. KATILIMCI 3 "Bir kez evlendim. 12 yaşında bir oğlum var, boşandığımızda 3 yaşındaydı. 2011'de sebep yokken ayrıldık. Eşim ilk önce Rus bir kadınla evlenmiş, ondan ayrildlktan sonra benimle evlendi. Dil bilmiyordum, öğrenemedim. Eşim eski evleri ylkıyordu, mermer döşüyordu bu yüzden evde pek durmuyordu, ben de yalnız kallyordum. Aslen Afyonluyum. Evlenerek yurt dişına gittim orası bana yaramadı kafayı yedim geldim. 20 yaşında hastalandım aslında, 28 yaşında da evlendim. 20 yaşındayken Lustral kullaniyordum, Psiko'lu bir şey dediler bana. (Psikoz demek istiyor.) Ondan önce de hocaya götürdüler beni şeytan musallat olmuş dediler, müftüye okuttular. Boğazımı sikıyorlardl, türbeye götürdüler beni, ermiş mezarlarına gittim, aklı çok karışmış dedi. Sabah ezaninda dereye girip arkasına bakmadan gitsin dediler, yaptım iyi oldum. Ama üç harfliler hala var korkutuyorlar beni, sesler geliyor kulağıma. Bazı şeyler hayal gibi geliyor. Evlenip gittiğime pişman oldum, dönmek istedim ama eşim bana şiddet uyguladı ama şiddet göstermesine ben de neden oldum, onu tetikledim. Doğumdan sonra, lohusa döneminde daha çok hastalandım. Evde yalnız kalmıştım nasıl oldu, neden oldu hatırlamıyorum ama hastalandım. 2 sene orda yaşadım, hastalı̆̆ım artınca da memlekete geldim. Eşim doktora götürmedi beni, memlekete gelince doktora gittim. Eskişehir'de Tip Fakültesinde yattım. Önceden annem baklyordu ama annem artık 70 yaşında bana bakamad. 7 senedir de bakım merkezindeyim. Oğlum yılda bir beni görmeye gelir. Eşimden ve çocuğumdan ayrıldım, çocuğuma bakamadım diye psikolojim bozuk. "Şeklinde düşüncelerini belirtmiştir. 
Katılımcı yaşadıklarını ifade ederek hastalığının dil bilmeden başka bir ülkede çoğu vaktini yalnız geçirmek zorunda kalmasından dolayı başladığını ve doğum yapmasıyla birlikte lohusalık döneminde hastalık belirtilerinin arttığını belirtmektedir. Eşinin kendisini doktora götürmemesi, kendisine şiddet uygulaması da hastalığın belirtilerinin artarak devam etmesine neden olmuştur. Hamilelik süreci; şizofreni hastalarında ilaç kullanımının azaltılması veya bırakılması, yaşanılan bu yeni duruma adaptasyon sağlanamaması gibi hasta bireyi olumsuz etkilemektedir. Şikâyetlerin artması, kendine ve bebeğe zarar verme durumuna dahi gidebilmektedir. Hastanın yakınlarından, çocuğundan ayrı kalışı hastanın psikolojisini negatif olarak etkilemektedir. Eşinin hastayı bakımı için memlekete annesinin yanına getirmesi, bakıma muhtaç durumdaki hastaların anne gibi birinci derece yakınları tarafından bakımının üstlenildiğini göstermektedir. Bu vakada da yardım arama davranışı olarak dini çevrelere başvurma görülmektedir. Sesler duyması, korkularının olması gibi belirtiler hastanın almış olduğu şizofren tanısının özelliklerini yansıtmaktadır.

Diğer katılımcı olan KATILIMCI 4 "Ankara'da yatıl askeri okulu kazandım. 22 yaşında rahatsızlandım. Depresyonum başladl, ben psikolojik olduğunu düşünemedim, KBB (kulak, burun, boğaz)'den kaynaklanıyor zannettim çünkü ameliyat olmuştum oraya bağladım. Sonra GATA (Gülhane Askeri Tıp Akademisi)'da yattım çok kez, Şizofreni dediler. 25 yıldır artık atak ve yatışım olmuyor. Hastalı̆̆ım durup dururken oldu, ĕglenceli aktif biriydim. Ama babamın sorumsuz oluşu da etkiledi. Küçük yaştan çalışmaya başladım. Babam eve bakmazdl, bizlerle ilgilenmezdi, annemi aldattı̆̆ın gözlerimle gördüm bunlar da travma oluşturdu bende." Şeklinde cevap vermiştir.

Katılımcı hastalığının sebepsiz yere başladığını fakat aile içi ilişkilerde ve iletişimde sorunlar yaşamasından, aile birlikteliğinin sarsılmasından kaynaklı olarak travmalar yaşadığını belirtmiştir. Hastanın ataklarının ve hastaneye yatış sayısının azalması hasta için olumlu bir göstergedir.

Soruya cevap veren bir diğer katılımcının olan KATILIMCI 5'in cevabı; "2 kez evlendim boşandım. Illk eşimden 2012'de bu hastalı̆̆ım yüzünden ayrlldım, o zamandan beri hastalığım devam ediyor. Nasıl başladığını bilmiyorum, hep uyku sorunum oldu. 2014'te ikinci eşimden ayrıldım. Bir oğlum var, annesiyle İstanbul'da yaşlyor. Iki evliliğimden de bu illet yüzünden ayrlddım, bir yuva kurdurtmadı bana bu hastalık. Çok yattım hastanelerde, şiddet uyguladım, bağırıp çağırdım eşlerime, anneme; ben olsam bana katlanamazdım onlar iyi bile dayandılar bana." Şeklindedir.

Katılımcının hastalığından dolayı hayatındaki insanlara şiddet uyguladığı, bunun dayanılmaz bir durum olduğu için onların da kendisini terk ettiği ve hastalığından kaynaklı olarak bir aile kuramadığı bunun da farkında olduğu belirtildi. Hastanın beyanı; hastalığın evlilik ve aile yaşamını olumsuz etkilediğinin, çoğu evliliği boşanmayla sonuçlandırdığının, aile birlikteliğinin bozulmasına neden olduğunun göstergesidir.

Çevresi ile ilgili iletişim kurmakta sıkıntı çeken 5 kişi bulunmaktadır. Diğer 4 kişi ise herhangi bir sorun yaşamamaktadır. Çevresi ile iletişim kurmakta sıkıntı yaşayan 4 kişinin 1'i kadın, 3'ü erkektir.

Çevresi ile iletişim kurmakta sıkıntı yaşayan KATILIMCI 3 soruya şu şekilde cevap vermiştir: "Bazen insanlarla konuşurken sıkıntı oluyor, bazen de olmuyor. Rahatsız olduğum için konuşmamaya çalışıyorum çok fazla. İçine kapanık biriyim, toplu yerlere fazla giremiyorum. Babam bize karşı disiplinliydi, kardeşlerim cesaretli ama benim cesaretim yok, ondan olabilir."

Katılımcı cevabıyla iletişim kurmamasının nedenini disiplinli bir ailede yetişmesine ve bu yüzden de cesaretli olamamasına bağlamaktadır. 
Yine başka bir katılımcının olan KATILIMCI 5'in soruya cevabı şöyledir: "Dışarı hiç çıkmıyorum. Neden bu hale geldim diye düşünüp duruyorum. Kimseyle konuşmak istemiyorum."

Hasta yukarıdaki beyanıyla hastalığı ile ilgili kabulünün olmadığını, sosyal açıdan olumsuzluklar yaşadığını, iletişim kurmaktan kaçındığını belirtmektedir.

Katılımc1 6 soruya cevap vererek kendini şu şekilde ifade etmiştir: "Kimseyle samimi olmayı tercih etmiyorum. Kimseye güvenmiyorum, şüpheciyim. Bir kez eski erkek arkadaşıma güvendim, güvenimi yerle bir etti. 5 yıllık ilişkim bitti gitti. Her şey güzelken iyi, bir baklyorsun aslında yokmuş."

Katılımcı ilgili soruya verdiği cevabı ile güven duygusunun olmadığını ve şüphecilik yaşadığ 1 için iletişim kurmak istemediğini ifade etmiştir. Hasta güven duygusunun olmamasını yaşadığı olumsuz bir tecrübeye bağlamaktadır.

Şizofreni hastalarının hastalığı ile başa çıkma yöntemleri olarak verdiği cevaplar belirtilmiştir. Katılımcı 1 hastalığı ile ilgili başa çıkma yöntemini şu şekilde ifade etmiştir: "İlaçlarımı kullanıyorum. Toplum Ruh Sağlığı Merkezi'ne (TRSM) geliyorum, boyama yapıp kafa dağıttyorum, futbol, basketbol oynuyorum. Toplum

\section{Ruh Sağllğı Merkezi'nde bize değer veriyorlar, anliyorlar."}

Katılımcı cevabıyla TRSM'ni hastalığı ile başa çıkmada etken olarak görmektedir. TRSM'de yapılan çalışmaların kendisine iyi geldiğini ve kendisine değer verilip, başkaları tarafından anlaşıldığını belirtmiştir.

Katılımcılardan diğeri KATILIMCI 2 soruyu şöyle cevaplamıştır: "Yalnızlığı seviyorum, yalnız kalmaya çalışıyorum. Gürültüllü ortamları kafam götürmüyor. Yalnızlığı da kendi kendime sohbet ettiğim için seviyorum."

Katılımcı verdiği bu cevapla kendince baş etme yöntemi olarak yalnız kalmayı tercih ettiğini belirtmiştir. Hastanın kendi kendine konuşup sohbet etmesi hastalığının belirtisi olabilmekte ve hastalığının aktif döneminde olabileceğini göstermektedir.

KATILIMCI 3 soruya cevap vererek kendini şöyle ifade etmiştir: "Hastalığım yalnız kalınca artıyor, susuyorum, kabulleniyorum, daha kötü şeyler olmasin diye kendimi tutuyorum."

Katılımcı ifadesi yalnız kalmasının kendisine iyi gelmediğini söyleyerek, baş etme mekanizmalarının bireysel olduğunu bir kez daha bize göstermektedir.

Sorulan soru ile ilgili olarak KATILIMCI 5 "Dışarı $m \imath$ çıkabiliyorum bu ă̆rılar yüzünden, keşke evlenmeseydim bunlar olmazdl belki o zaman. Kendi kendimi yiyip bitiriyorum. "Şeklinde cevap vermiş̧ir.

Toplumsal bir kurum olarak aile kurma fikri, sağlıklı bireyler kadar ruhsal hastalığı olan bireyler üzerinde de etkilidir. Ruhsal hastalığı bulunan bir bireye sahip aileler; evlenmenin hastalığa iyi geleceğine, hatta çocuğu olmasının hasta bireyi hastalığından uzaklaştıracağına inanmaktadırlar, böyle olunca da ruhsal hastalığı bulunan bireyler de evlenmektedirler. Evlilik bazen hastalığa olumlu yönde etki ederken bazen de evliliğin getirdiği roller ve sorumluluklar bireyde hastalığının olumsuz seyretmesine neden olmaktadır. Bu müracaatçı hastalığıyla baş edememesinin nedenini evlenmesine bağlamaktadır.

Bir gününüzü nasıl geçiriyorsunuz sorusuna katılımcılar çeşitli cevaplar vermişlerdir. Katılımc1 1 soruya verdiği cevabı ile kendini şöyle ifade etmektedir: "Hafta içi hep TRSM (Toplum Ruh Sağlığı Merkezi) 'deyim sabah sekiz ile akşamüstü dört arasında. Hafta sonları da köpek gezdiriyorum, bahçeyle ilgileniyorum. Her gün kendime bir not veriyorum, bugün altı verdim (24.02.2020) çünkü mutluyum, kızım bana ayakkabı almak için para gönderecekmiş. Verdiğim en yüksek puan 7 oluyor zaten, çünkü her günüm birbirine benziyor." 
Katılımcının verdiği cevaptan da anlaşılacağı gibi TRSM ruhsal hastalığı olan bireylere sahip ailelerin yükünü hafifletmekte önem arz ediyor. Bireyler gün içerisinde belirli saatlerde TRSM (Toplum Ruh Sağlığı Merkezi)'ye gelerek boş zamanlarını değerlendirirken, çeşitli sanatlarla ilgilenirken ailelerde kendi işlerine yoğunlaşmakta ve kendilerine zaman ayartmaktadırlar. Aynı zamanda hasta kendisiyle benzer rahatsızlıklara sahip hastalar ile bir araya gelerek, grup terapilerine katılarak; duygularını dışa vurma, yalnız kalmadığını hissetme gibi durumlar yaşamaktadır. Bu da hastaların sosyal kapasitesinin, becerilerinin gelişmesini sağlamaktadır.

Kişisel bakımını kendisi yapan kişi sayısı 5 'tir. Diğer 4 kişi ise herhangi bir yakını ya da bakım merkezi çalışanının desteğini alarak kişisel bakımını yapmaktadır. Şizofren hastası olan 4 kişinin intihar teşebbüsü bulunuyorken, 5 kişinin intihar teşebbüsü bulunmamaktadır. Bunlardan 2'si kadın 2'si erkektir. Bu kişilerin 2'si boşanmıştır, 1'inin eşi vefat etmiştir ve 1'i evlidir.

İntihar olgusu şizofreni hastaları için risk unsuru taşımaktadır. İntihar, şizofreni hastasının yaşamını zor hale getirmektedir. Bu konuda hastalara intiharla ilgili düşünceleri sorulmuştur. KATILIMCI 3 "Intiharları düşündüm, geri vazgeçtim. Çok kalkıştım; asmaya kalktım, zehir içmek için yatağın altına zehir koyup öyle yatıyordum, hala bazen hap içip öleyim diyorum. Ölüm benim için kurtuluş yolu diye düşünüyorum, çok duygusal biriyim." Şeklinde cevap vermiştir.

Katılımcı beyanıyla çeşitli intihar teşebbüslerini düşündüğünü ve hala düşünüyor olduğunu, bunun sebebinin de duygusal yapıda olmasından kaynaklandığını belirtiyor.

Soruya cevap veren KATILIMCI 4 kendini şu şekilde ifade etmiştir: "İntihar düşüncesi vardı ama intihar teşebbüsüm olmadı. Hayattan zevk alamıyordum."

Katılımcının soruya verdiği cevapla, katılımcının yaşama dair umutsuzluk düşüncesinin kendisine intiharı düşündürdüğü öğrenilmiştir.

Diğer bir katılımcı, KATILIMCI 7 "İple, bıçakla intihar ettim 2-3 kez ama artık intiharı düşünmüyorum." Şeklinde cevap vermiştir.

Katılımcıların hastalıkla birlikte hayatınızda neler değişti sorusuna verdiği cevaplardan bazıları şunlardır: KATILIMCI 1 "Hastalıkla birlikte mesleğimi kaybettim, arkadaşlarımı kaybettim, kardeşlerim konuşmamaya başlad, manevi yönden çöktüm ben. Çocuklarım ve onların gelecekleri ile ilgili endişelerim var, hastalıkla ilgili de hastalı̆̆a bir teslimiyet var hocam bende. Böyle gelmiş böyle gider." Şeklinde cevap vermiştir.

Katılımcı hastalığıyla birlikte hem işini kaybetmiş hem de sosyal çevresinde kayba uğramıştır, bu da katılımcının sosyal desteğinin azaldığını da ifade etmektedir.

Soruya cevap veren diğer bir katılımcı olan KATILIMCI 3, şu şekilde kendini ifade etmiştir: "Çok şey değişti. Evlilik, çocuk doğurmak beni mahvetti. Beynim düşünmekten zorlanıyor artık, düşündü̈ç̧e de kuruyorum, düşünceler geliyor bana. Keşke bir mesleğim olsaydl. Çok düşünmek, kötüyü düşünmek beni çok yordu."

Katılımcı cevabıyla evlenmenin, çocuk doğurmanın hastalığını tetiklediğini belirtmektedir. Mesleğinin olmasını da; bir uğraşısının, işinin olmasının kendisini olumlu etkileyeceğini düşündüğü için istemektedir. Sosyal yalıtılmışlığın hastalığını olumsuz olarak etkilediğini itiraf etmektedir.

KATILIMCI 4'ün soruya verdiği cevap şu şekildedir: "Topluma anlatamıyorum hastalı̆̆ımı. İlaçlarla sürekli baş başayım bu oldu, kilo aldım. Alıştım artık buna."

Katılımcı hastalığının ilaç kullanmasına neden olduğunu, bunun da kilo yaptığını ve toplum tarafından anlaşılmamasına sebep olduğunu belirtmektedir. Hasta kabul ve saygı görmek istediğini ama bunu anlatamadığını ifade etmektedir. 
Soruya cevap veren KATILIMCI 5 "Ne değişecek yatağa bağıml oldum, (sürekli uyumak) ilaçlar içmeye başladım, terk ettiler beni. " Şeklinde kendini ifade etmiştir.

Katılımcı cevabıyla hastalığıyla birlikte terk edildiğini, sürekli uyku hali olmasından dolayı da yatağa bağımlı hale geldiğini belirtmektedir. Hasta hayatında belirgin olan şeyin ilaç, hastalık, hastane ve sosyal yalıtılmışlık olduğunu ifade etmektedir.

Katılımcılardan bir diğeri olan KATILIMCI 6 "Güvenmemeyi öğrendim, bu benim hayallerime, umutlarıma, mutluluğuma engel oldu." Diyerek kendini ifade etmiştir.

Hasta verdiği cevapla, güvenmek duygusunun aslında ne kadar önemli olduğundan ve diğer duygularla birlikte anlam kazanıyor oluşundan dolayı bireyin yaşamında nelere neden olabileceğinden bahsetmektedir.

Yine başka bir katılımcı olan KATILIMCI 7 "Çocuklarım eksik kald, çalışamadım, yetemedim onlara, hastanelerde yattım, kendimi öldürmeye kalktım." Şeklinde cevap vermiştir.

Hasta; çocuklarına olan sorumluluğunu yerine getiremediği için rol kaybının kendinde yarattığ psikolojik travmayı, bu nedenle intihara teşebbüs edişini itiraf etmektedir.

Hastalığının toplum tarafından anlaşılmadığını düşünen hastalar soruyu kendi bakış acılarına göre cevaplandırmıştır. Buna göre; KATILIMCI 1 "Ben deli değilim, herkes bana deli diyor eşim, akrabalarım... (Görüşme devam ederken ă̆lamaya başladı.) Toplum beni anlamıyor. Hastalığımdan kurtulayım diye, artık ölmekten korkmamak için mezar kazdırıp içine bile girdim ama olmadl, boğuluyor gibi oldum korktum. Bu hastalı̆̆ yenmek için insanların bana kötü kötü bakmaması için kendimi kefene de sardıracağım ama kefen pahalı." Şeklinde cevap vermiştir.

Müracaatçının hastalığından dolayı yaftalanması, ona takma adlar takılması ve kendisine bireyin onuruna yakışmayacak şekilde ifadelerle seslenilmesi müracaatçının toplum tarafından anlaşılmadığını düşünmesine neden olmaktadır. Sosyal çevresi tarafından kabullenilmek için korkularının üzerine gitmesi, bu yönde adımlar atması müracaatçının toplum tarafından kabul edilmeyi istediğinin ve ayrımcılığa uğramak istemediğinin göstergesidir.

KATILIMCI 3 “Markete gidince bana bakıp uzak duruyorlar, deliymişim gibi benden kaçıyorlar. Bana kötülük yapmak istiyorlar gibi geliyor. Kendimi kötü hissediyorum ama onlara aldırış etmiyormuş gibi davranıyorum. "Şeklinde kendini ifade etmiştir.

Katılımcının toplumsal bir alanda bakışlardan tedirgin olduğu ve bunun kendisinde korku yarattığı anlaşılmaktadır.

Soruyu cevaplayan KATILIMCI 4 kendini şu şekilde ifade etmiştir: "Söyleyemiyorsun bunu, ön yargılı davranıyorlar. Oysaki biz de diğer hastalıklar gibi hap kullanacağız ömür boyu, bu kadar. Tanımak lazım aslında kişiyi ama öyle yapmiyorlar maalesef."

Katılımcı ifadesi ile kendini ifade etmekten çekindiklerini, toplumun kendilerine ön yargılı davrandıklarını ama toplumun bireysel bazda her bir hastayı tanıma çabası içerisine girdiklerinde hastaları anlayacakları düşüncesini savunmaktadır.

Katılımcılardan bir diğeri olan KATILIMCI 7'nin cevabı şu şekildedir: “Anlaşılmıyor, çalıştırmıyorlar bizi. Hastalanıyorsun öylece bir köşede kalıyorsun."

Hasta soruya verdiği cevapla işsiz oluşu, işverenlerce kendisinin çalıştırılmıyor oluşu ile ilgili olarak toplum tarafından anlaşılmadığını düşünmektedir.

KATILIMCI 8 "Karşındaki kişiye bağlı olarak değişiyor. Eşim beni anladı ama arkadaşlarım anlamad. Üzerime geldiler." Şeklinde soruyu cevaplamıştır. 
Katılımcı ifadesi ile bireyin anlaşılma durumunun yine karşısındaki bireye ve bu kişinin yakınlık derecesine bağlı olduğunu ifade etmektedir.

Şizofren hastalarının hastalığ ile ilgili kendini destekleyen en az bir kişi bulunan kişi sayıs1 8'dir. Diğer 1 şizofren hastası ise hastalığ konusunda kimse tarafindan destek görmediğini belirtmektedir. Katılımcıların düşünceleri incelendiğinde: KATILIMCI 1 "Hastalandiktan sonra kardeşlerim benimle konuşmamaya başladl, o yüzden bize gelen giden pek olmaz. Abim kızını evlendirdi, bizi düğüne bile çağırmadı. Kayınvalidem desteklerdi, o da vefat etti. O ölünce çok üzüldüm. Şimdi eşim ve çocuklarım destekliyorlar beni. Kızım sayesinde banyo yapma sayım arttı, temizliğime daha dikkat etmem gerektiğini söylüyor. Üşendiğimden onlar demezse banyoya girmiyorum. Eşim ilaçlarımı takip ediyor." Diyerek kendisini ifade etmiştir.

Hasta; hastalığı ile ilgili çevresinden destek göremediğini, sosyal desteğinin azaldığını, kendisine destek olan kişilerce bakımını daha düzenli yapmaya başladığını ve ilaçlarını daha düzenli kullandığını belirtmektedir.

KATILIMCI 2 soruya şu şekilde cevap vermiştir: “Annem, babam öldü. Toplam 5 kardeşiz ama 3'ü öz, onlar da beni izinli çıkarıyorlar, ziyaretlerine gidiyorum. Bakım merkezindekiler, sağllkçılar bana daha çok destek oluyorlar, kardeşlerimi seneden seneye görüyorum."

Katılımcının beyanıyla, sağlık personellerini kendisine destek verenler olarak atfetmesi önemlidir. Bu durum da sosyal desteğin sadece birinci dereceden yakınlar tarafından değil de toplumun her kesiminden bireylerce verilebileceğini göstermektedir.

Yine farklı bir katılımcı olan KATILIMCI 3 "Sadece ailem destekçim, arkandayız diyorlar bana. Çok çektirdim onlara, erkek kardeşimi dövüyordum, yazık, bağırıp çağırıyordum. Onlara zarar vermemek için onlardan uzak duruyorum. "Şeklinde cevap vermiştir.

Hastanın verdiği cevap, ailenin varlığının önemini vurgulamaktadır.

\section{TARTIŞMA ve SONUÇ}

Yapılan bu çalışma şizofreni hastalarının sosyal hizmet bakış açısı ile değerlendirilip, sosyal hizmet müdahalelerinin üzerinde durmaya çalışan bir araştırmadır. Şizofreni hastalığ sosyal hizmet, bu iki konunun sağlıkla ilişkisi hakkında çalışmalar bulunmasına rağmen şizofreni ve sosyal hizmetin birlikte değerlendirilmesi ve bu konuda nitel bir çalışma yapılması üzerine çalışmalar yok denecek kadar azdır. Dolayısıyla yapılan bu çalışma alanına özgün bir çalışma niteliği taşımaktadır.

Araştırma sonuçlarına göre Kütahya İlinde şizofreni tanısı almış erkek hastaların tedavileri için hastaneye başvurularının fazla olduğu görülmektedir. Hastaların çoğunun çalışma geçmişi bulunmamaktadır. Araştırmaya katılan hastaların fiziksel ve psikolojik olarak gösterdikleri semptomların şizofreni hastalığının özellikleri ile örtüştüğ̈ bulgusuna ulaşılmıştır. Hastaların hastalıkları ile ilgili olarak geliştirdikleri baş etme yöntemlerinden çoğu bireysel aktivitelerden oluşmaktadır.

Sosyal yaşam açısından değerlendirildiğinde ise; şizofreni hastalığının belirtileri kontrol altına alınsa bile birey hastalığından dolayı arkadaş edinmede, topluma katılım sağlamada sorunlar yaşar. Bireyin sosyal işlevselliği azalır. Bu durumda hastaya sosyal beceri eğitimi verilmesi, hastanın topluma geri kazanılmasını olumlu yönde etkileyen faktörlerden biri olarak değerlendirilebilir. Şüpheci tutum, içe yönelme, iletişimde azalma, görsel ve işitsel halüsinasyon, konuşmalarda dağılma, öz bakımda yetersizlik şizofreni hastalarında sıklıkla görüldügünden; hastanın sosyal yaşama uyumunu artırmak, topluma geri kazandırılmasını sağlamak, hayat 
standartlarını geliştirmek, kaynakla ihtiyacı birleştirerek hastaların tedavilerine olumlu katkı sağlamak sosyal hizmetin görevleri arasında yer almaktadır.

Her araştırmada olduğu gibi bu araştırmada da kısıtlılıklar bulunmaktadır. Araştırmanın Kütahya ili ile sınırlı oluşu araştırmanın kısıtlılığıdır. Bu nedenle araştırma örneklem ile sınırlıdır. Bununla birlikte yapılan araştırmanın Kütahya ilinde bulunan şizofreni hastalarına yönelik olarak planlanan uygulamalarda ve hastaların sosyal işlevselliklerini artırmak yönünde yapılacak çalışmalarda etkili olacağı ifade edilebilir. Şizofreni hastalığına sahip bireylere ve yakınlarına sosyal beceri, sorun çözme becerisi, hastalıkla baş etme becerisi gibi kendi becerilerini geliştirecek ve bireylerin tedaviye uyumlarını artıracak eğitimler verilmesi, tedavi planına hastaların ailelerinin de dâhil edilmesi hastalığın sağaltımında önemli bir yer edinmektedir. Bu nedenle de bu tür hastalıkların tedavisinde yalnızca tıbbî müdahaleler değil sosyal hizmet müdahalelerinin de önemli olduğu ortaya çıkmaktadır.

\section{5. ÖNERİLER}

Araştırma sonucunda elde edilen bulgulara yönelik bilimsel öneriler sunmak, çalışma hakkında verilen sonuçlar kadar son derece önemlidir.

Örneğin;

- Hastanın tedaviye uyumunu artırmak için kullandığı ilaçlar hakkında eğitim verilmesi, iletişim becerisi konusunda eğitim verilmesi ve günlük yaşam aktivitelerini yapmayı sağlamalarına yardımcı olunması,

- Ruhsal hastalığa sahip bireylerin bakım verenlerine yönelik eğitimler oluşturularak hastalarına yönelik tutumun olumlu yönde ilerletilmesi,

- Tedavi programının aksamadan işeyebilmesi için hasta-aile-tedavi ekibinin iş birliği içerisinde hareket etmeleri,

- Hastanın sosyal yaşamlarına uyumunu kolaylaştırmak ve işlevselliklerini artırmak için mesleki ve beceri kursları, spor müsabakaları, sinema, sanat faaliyetleri gibi sosyal kültürel faaliyetleri etkin hale getirilmesi,

- Sosyal hizmet mesleği ile ilgili kurumlarla iş birliği sağlanarak önleyici tedbir konusunda sosyal sorunların çözümünde müdahaleler geliştirerek stresörleri azaltmak adına çalışmalarda bulunulabilir.

\section{KAYNAKCA}

Aktürk Demir, A. (2011). A'dan z'ye hastalıklar. İstanbul: Ozan Yayıncılık.

Bademli, K. ve Çetinkaya Duman, Z. (2013). Şizofren hastalarının bakım verenleri. Psikiyatride Güncel Yaklaşımlar, 5(4), 461-478. [Çevrim-içi: http://www.psikguncel.org/archives/vol5/no4/cap 05 29.pdf], Erişim tarihi: 29.05.2020.

Cüceloğlu, D. (2011). İnsan ve Davranışı. Remzi Kitabevi.

Danış, Z. (2007). Sosyal hizmet mesleği ve disiplininde sosyal politikanın yeri ve önemi. Toplum ve Sosyal Hizmet Dergisi, 18(2), 51-64.

Demirkol, M.E. ve Tamam, L. (2016). Psikiyatrik bozukluklarda tedavi uyumu. Psikiyatride Güncel Yaklaşımlar, 8(1), 85-93. [Çevrim-içi: http://www.cappsy.org/archives/vol8/no1/cap_08_01_08.pdf], Erişim tarihi: 29.05.2020.

Deveci, A. ve Esen Danac1, A. (2006). Şizofrenide erken uyarıcı belirtiler. Düşünen Adam, 19(1), 20-23. [Çevrim-içi: https://dusunenadamdergisi.org/storage/upload/pdfs/1586437221-tr.pdf], Erişim tarihi: 29.05.2020.

Dilbaz, N. ve Enes Darçın, A. (2011). Şizofreni ve madde kullanım bozukluğu eş tanılı hastalarda tedavi. Klinik Psikofarmakoloji Bülteni, 21(1), 80-90. [Çevrim-içi: http://www.psikofarmakoloji.org/pdf/21 1 14.pdf], Erişim tarihi: 29.05.2020. 
Erbaş, O. (2018). Psikiyatrinin kara kitabı: beyninizi yakmaya hazır mısınız?. İstanbul: Siyah Kuğu Yayınevi.

Gülseren, L. (2002). Şizofreni ve aile: güçlükler, yükler, duygular, gereksinimler. Türk Psikiyatri Dergisi, 13(2), 143151.

Hasgül, E. (2016). Evde bakım hizmetlerinde sosyal hizmet uzmanlarının işlevleri ve rolleri. Tıbbi Sosyal Hizmet Dergisi, (7), 14-21. [Çevrim-içi: https://dergipark.org.tr/tr/pub/tshd/issue/52312/684981], Erişim tarihi: 29.05.2020.

Hökelekli, H. (2009). Psikolojiye Giriş. Düşünce Kitabevi Yayınları.

Işıkhan, V. (2006). Ruh hastası evsiz kadınların sorunları ve sosyal hizmet yaklaşımları. Toplum ve Sosyal Hizmet Dergisi, 19(1), 37-52.

Karşıdağ, Ç., Alpay, N. ve Kocabıyık, A. Şizofreni ve sigara bağımlılı̆̆ı. Düşünen Adam; 2005, 18(1): 13-20. [Çevrim-içi: https://dusunenadamdergisi.org/storage/upload/pdfs/1587720739-tr.pdf], Erişim tarihi: 29.05.2020.

Özbesler, C. (2011). Sosyal hizmet eğitiminde aile tedavisi yaklaşımları ve aileye yönelik sosyal hizmet. Sosyal Hizmet Eğitiminde Bildiriler Sempozyum Kitabı (120-123). Ankara.

Yakıncı, C. (2015). Sağlıklı yaşam için erken tanı rehberi. Ankara: Akademisyen Tıp Kitabevi. 


\section{Extended Summary}

\section{Social Life and Social Work Relationship of Schizophrenic Patients: Kütahya Sample Extended Summary}

The study was conducted on the evaluation of the lives of schizophrenic patients in the context of social work. The study was conducted with 9 people using qualitative research technique. In the research, semi-structured interview and observation technique was used as data collection tools. It was seen that awareness of the patients was provided. In addition, it has been understood that the negative aspects of schizophrenia disease and the symptoms accompanying the disease have positive effects on patients and their relatives by developing mechanisms to cope with focusing on the strengths by the individual and his social environment.

In the findings obtained from the research, it was observed that schizophrenia disease negatively affects the functions of the family, the functions of the individual, problem solving, coping skills, communication, and general functions. In addition, it is aimed to reveal the social service intervention programs that schizophrenia patients need. Suggestions for evaluating schizophrenia disease from a social work perspective are also included. Therefore, as a result of the study, important findings were obtained for the field of social work.

Schizophrenia is a psychiatric disorder that causes impairment in the attitudes and behaviors of the person, in understanding and perceiving the reality, thus causing the individual to experience familial, social problems. While the features such as chronic course, regular drug use, long-term treatment are common in schizophrenia; Common symptoms such as not looking positively towards the future, loss of social life and social role, deterioration in social functionality, communication problems, problems in maintaining work, and decreased leisure activities are observed.

Symptoms such as having self-talk, having hallucinations, hospitalization in the psychiatric center, taking responsibility, having problems, and inconsistent behaviors are the main symptoms of schizophrenia. In addition, patients not knowing where the danger will come from, there may be situations that can be deceived, risk assessment and problems, sudden and unexpected attitudes and behaviors are other symptoms of schizophrenia.

Due to the effect of the disease, the inability of individuals to work, and therefore not to participate in social and economic life, and to have environmentally damaging behaviors affect the individual and his social environment negatively. Participants have difficulties in self-care, insufficient social functionality, inconsistencies in their general attitudes and behaviors, and difficulties in establishing healthy communication lead to inward closure and problems of adaptation.

The fact that the social support of the patients affects the process of their diseases is one of the biggest factors in ensuring the recovery of the patients to the society. Families provide the social support of the patients in the first place. Individuals who provide social support to patients also take on roles and responsibilities, such as helping patients to do their personal cleaning, and supporting them in developing skills in contributing to their daily routine. At the same time, it is important for patients to fight this disease for a long period of time, as well as to behave appropriately for treatment and to use their medicines radaptatio.

It is a problem that can be improved, although it cannot be fully achieved in psychiatric disorders, as well as a spiritual and social well-being. Although life standards are increased in schizophrenia, the disease reappears when faced with mold trauma in remission. This causes complete well-being. The solution to this problem is only a multi-faceted perspective and the contribution of interdisciplinary studies. It is possible to raise the living standards of patients 
with an interdisciplinary approach. This is achieved by increasing the quality of daily life. One of the important professions in this field is the social work profession. In light of all this information, people with schizophrenia disease; Problems such as the problems experienced in coping with the symptoms of the disease, interpersonal relations, business life are evaluated in terms of the relationship between the phenomenon of health and illness and social work. In this framework, it is assumed that social work is an important area in rebuilding the life world of patients.

Confidentiality and privacy are essential when working with patients who need social work intervention. In the professional meeting with the patients, intervention planning is made for the patients. During the treatment process, a strengthening, informative and introducing community resources are played to patients and their relatives. The aim of medical social work practices is to improve patients' basic health conditions and to make them less negatively affect the psychosocial aspects.

Patients experience restlessness, excessive sleep or excessive insomnia, a desire to participate in social activities. The high level of anxiety of the family and the sick individuals themselves increases the importance of education in using the motivation of the individual and their relatives in a positive way. It is of utmost importance to emphasize the positive aspects of the sick individuals, to make them feel understood, to train daily life skills, to express themselves in order to increase their communication skills and to perform activities to understand and respond to what has been told. Participation in social activities should be supported, and efforts should be made to raise awareness of responsibility. Community integration cannot be ensured unless the human approach is based on a certain basis and discipline. 